
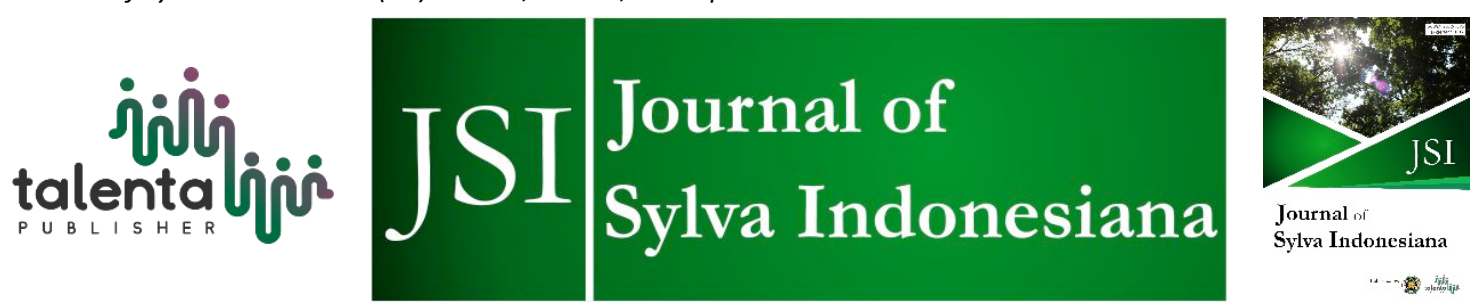

\title{
The Valuation of Thinning Effectivity Based on Increment Respond of Natural Forest Log Over Area
}

\author{
Farida Herry Susanty ${ }^{1 *}$ \\ ${ }^{I}$ Researcher on Dipterocarps Research Centre, Jl. A. Wahab Syahranie No. 68, Samarinda 75119 , \\ Sempaja Sel., Samarinda Utara, Kalimantan Timur, Indonesia
}

\begin{abstract}
Efforts to increase the natural forest productivity were conducted using several ways through thinning, but the effectiveness is not well known yet. The research aims to evaluate the effectiveness of thinning techniques to logged-over natural forests based on the response of the stand increment. The study design was an 11-year-old logged-over natural forest stand that was carried out systematic thinning, thinning based on built trees, and without treatment with 24 ha. Data collection is done by census inventory of trees with a limit diameter of $10 \mathrm{~cm}$ per 2 years periodically. Stand conditions in the research plot varied in the value range of density (419-510 stems $^{-1}$ ) and the base plane (22.66-28.20 $\mathrm{m}^{2} \cdot \mathrm{ha}^{-1}$ ), which were not too wide. The results of the calculation of the base plan of the stand show that systematic thinning yields a more significant stand increment $(0.78-1.95$ $\mathrm{m}^{2} \cdot \mathrm{ha}^{-1} \cdot 2 \mathrm{th}^{-1}$ ) compared to thinning based on built trees and without treatment. Thinning gives more responsive results for the Dipterocarp species group (the increment value is almost twice to normal) than non-Dipterocarp. Based on the regression analysis, the period's function has a correlation between $25-33 \%$ to the basal area increment. A systematic thinning technique approach that is more appropriate for increasing stand productivity.
\end{abstract}

Keyword: Basal Area, Density, Stand Increment, Thinning

Received 02 July 2020 | Revised 17 July 2020 | Accepted 26 August 2020

\section{Introduction}

Forests stand condition after logging have differences in density, structure, and basal area compared to primary forests [1]-[2]. Maintenance of forest stands after logging in production forests aims to prepare potential positions that meet production targets. The technique used is mainly of stand density management because the density is the primary stand indicator and is the easiest way to manipulate for increasing stand productivity at the next cutting rotation [3]$[5]$.

\footnotetext{
*Corresponding author: Dipterocarps Research Centre, J. A. Wahab Syahranie No. 68, Samarinda 75119, Sempaja Sel., Samarinda Utara, Kalimantan Timur, Indonesia E-mail address: fhsusanty@gmail.com 
Growth is a change or increases in size (dimensions) of living organs in a tree over its life cycle, which causes changes in the height, diameter, and volume [6]-[7]. The growth of individual trees or stand resulted from total interaction from genetic traits and their environment. The difference in the pattern of growth of the same species at the same location is greatly influenced by ecophysiological factors [1],[8]-[9]. The growth response of individual trees based on growth space will form different growth of stands [4],[10]-[11].

Management of natural forests after logging plays a vital role in ensuring forest direction stands growth towards sustainable yields [12]-[13]. It is mainly an effort to restore or increase the productivity conditions of production forest stands. The treatment of growing productivity, among others, were through pruning and thinning [14]-[15]. Regulation of stand density by thinning can affect the structure and production of old stands [5], [11]. The study was conducted on secondary lowland rainforest conditions after logging with initial production status. The measurements were observed the response or effect of different thinning techniques on other stands on forest growth rate. The research aims to determine the effectiveness of thinning techniques application in logged-over natural forests based on the valuation of stand increment.

\section{Research Method}

\subsection{Research Location}

The study was carried out on the STREK (Silvicultural Technique for the Regeneration of Logged Over Forest in East Kalimantan) plot, located in the Kawasan Hutan Dengan Tujuan Khusus (KHDTK) of the Labanan forest research station. The Labanan forest station is located in Labanan Village, Berau Regency, East Kalimantan. Geographically, KHDTK Labanan is located between $117^{\circ} 10^{\prime} 22^{\prime \prime}-117^{\circ} 15^{\prime} 35^{\prime \prime}$ East Longitude and $1^{\circ} 52^{\prime} 43$ "-1 $1^{\circ} 57^{\prime} 34^{\prime \prime}$ North Latitude.

The research plot is a permanent plot built-in 1990 with the initial condition being the 11-year old logged-over natural forest. Then thinning was carried out in 1991-1992. Observation and measurement of thinning impacts on stands are carried out every two years. Following the Indonesian Selective Cutting and Planting (TPTI) System guidelines, the term spacing is generally stated as clearing. The minutes of the permanent plot are as follows:

a) Systematic clearance of stands (PS) carried out on all non-commercial trees with a diameter of $\geq 20 \mathrm{~cm}$ by poisoning using herbicides. The average stand is not more than $35 \%$ of the total base field.

b) Clearing based on canopy competition to fostered trees (PPB) is to turn off noncommercial tree species with $\mathrm{a} \geq 20 \mathrm{~cm}$ diameter, which are contenders around commercial type trees (radius $\pm 10 \mathrm{~m}$ ). At the same time, non-commercial trees with a diameter of $\geq 40 \mathrm{~cm}$ are retained. The clearing is carried out by poisoning using a herbicide with a maximum of $35 \%$ of the base field area. 
c) The plot without treatment (control / CTR).

\subsection{Methods}

The plot was designed in $200 \mathrm{~m} \times 200 \mathrm{~m}$ (4 ha) divided into four subplots with $100 \mathrm{~m} \times 100 \mathrm{~m}$ (1 ha). The research plots were three variations of the condition of logged-over natural forests, six plots with a total area of research plots of 24 ha.

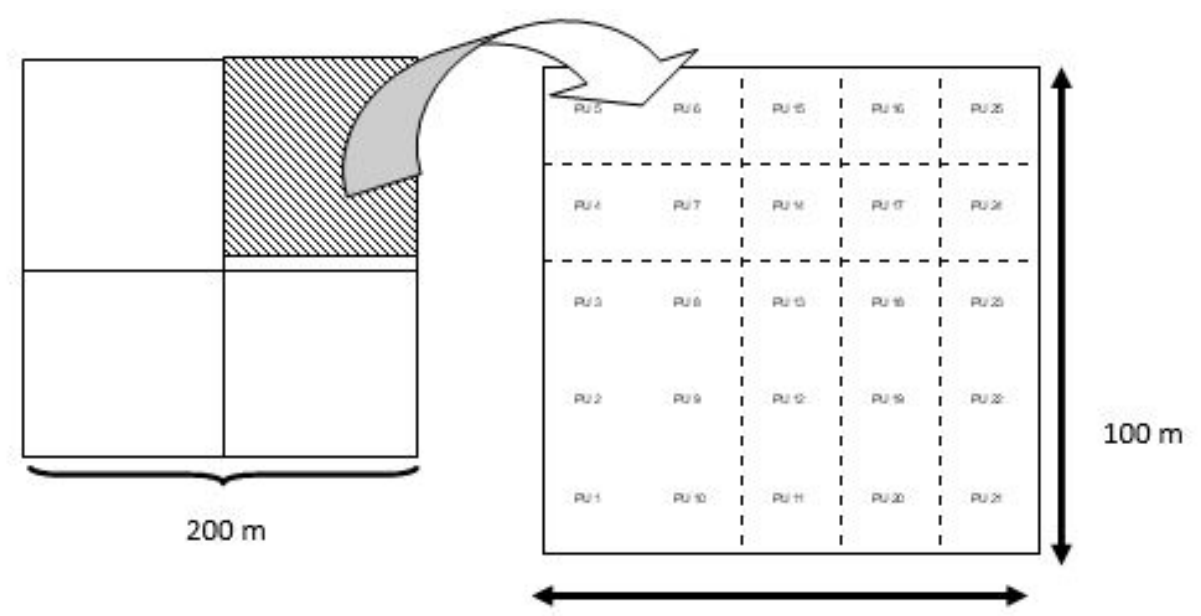

Where : Permanent plot measuring $200 \mathrm{~m} \mathrm{x} 200 \mathrm{~m}$ (4 ha) which is divided into sub plots $100 \mathrm{~m} \mathrm{x} 100 \mathrm{~m}$ (1 ha) with sub subplots measuring $10 \mathrm{~m} \times 10 \mathrm{~m}$

Figure 1 Design of research plot

Stand data were collected by field inventory using census in a research plot for all tree species (limit diameter is $10 \mathrm{~cm}$ ). This study uses measurement data from 1990-2015 (observations before clearing to 23 years after clearing).

\subsection{Data Analysis}

Periodic annual increment (PAI) calculation is assumed to grow tree dimensions every two years. Calculation of stand increment is based on basal area increment $\left(\mathrm{m}^{2} \mathrm{ha}^{-1} 2 \mathrm{th}^{-1}\right)$ in Dipterocarpaceae, non-Dipterocarpaceae groups and all types in each forest stand condition after clearing is calculated based on the following formula [16]-[17]:

$$
r B D_{i}=b d_{o}-b d_{i}
$$

Where: $\mathrm{rBD}_{\mathrm{i}} \quad=$ increment basal area of stands $\left(\mathrm{m}^{2} \mathrm{ha}^{-1} 2 \mathrm{th}^{-1}\right)$

$$
\begin{aligned}
& \mathrm{bd}_{\mathrm{o}} \quad=\text { basal area of initial measurement stands }\left(\mathrm{m}^{2} \mathrm{ha}^{-1}\right) \\
& \mathrm{bd}_{\mathrm{i}} \quad=\text { basal area of subsequent measurement stands / every } 2 \text { years }\left(\mathrm{m}^{2} \mathrm{ha}^{-1}\right)
\end{aligned}
$$


The form of increment equation is arranged based on regression analysis of the relationship of measurement period to each increment. The regression equations were linear, polynomial, exponential, and logarithmic equations.

\section{Results and Discussion}

\subsection{Density and basal area of the stand after logging}

The density and basal area of the stand after clearing by different techniques over 23 years of observation have dynamic growth patterns. During the observation time in the research plot, the stand density ranged from 419-510 tree ha ${ }^{-1}$ to an average of 472 tree ha ${ }^{-1}$. The density is similar to conditions with logged-over forests with a variation in the age of 4-33 years in the East Kalimantan region, which ranges from 284-671 tree $\mathrm{ha}^{-1}$ [2],[18]. While the value of the basal area of stand in the research plot ranged from 22.66-28.20 $\mathrm{m}^{2} \mathrm{ha}^{-1}$ with an average of $24.39 \mathrm{~m}^{2}$ $\mathrm{ha}^{-1}$. This basal area's value is to meet the range of the basal area value of secondary forest stands after logging, which ranges from 18.11-32.7 $\mathrm{m}^{2} \mathrm{ha}^{-1}$ [18]. Fluctuations in the density and basal area of the stand with clearing techniques (both systematically and based on target trees) are presented in Figure 2 below.

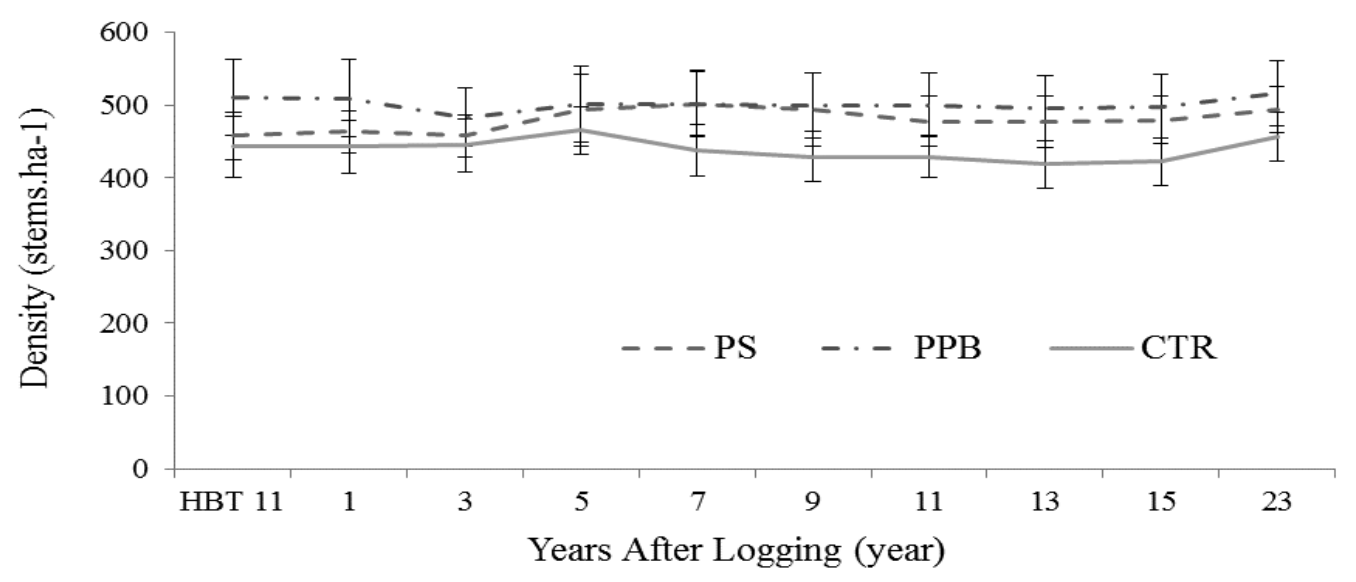

(a)

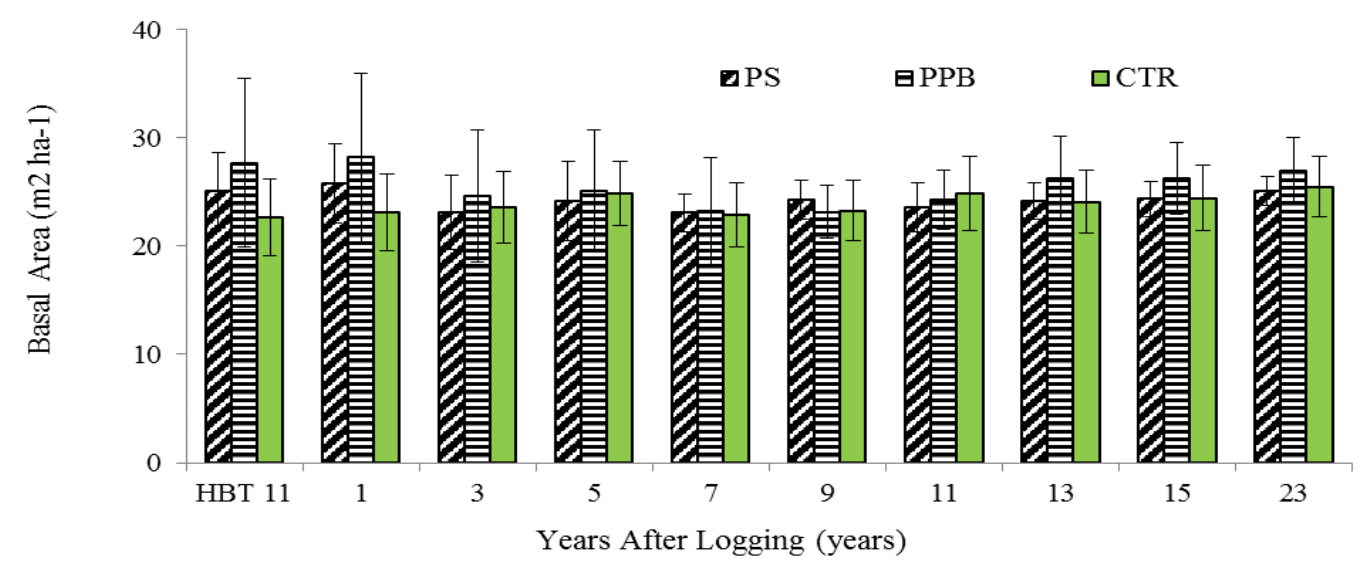

(b)

Figure 2 Stand conditions with different clearance techniques based on (a) average stand density $\left(\right.$ stand ha $\left.{ }^{-1}\right)$ and (b) average base field $\left(\mathrm{m}^{2} \mathrm{ha}^{-1}\right)$ 
The condition of forest stands after logging influenced by the period after logging and growth rate. Canopy opening due to the clearing process is expected to support growth or increase both individuals' increment rate and stands. An optimal opening rate will support optimal growth [5],[11],[19].

The results showed that logged-over forests had lower basal area values compared to primary forests [7]. The degree of stand restoration varies based on the initial stand condition, the felling technique, and species groups. It shows that the stand's growth pattern is an ecophysiological function, including the influence of the given treatment [2],[14]. The number of trees and stand structures that describe the level of stand availability at each stand growth stage influences the regeneration ability or growth of stands [5],[8],[14],[19].

\subsection{Periodic Stand Increment}

The value of stand increment based on the basal area was divided into Dipterocarpaceae and non-Dipterocarpaceae. The species periodically measured every two years after logging with different clearances after 23 years. Based on the increment value of standing stand with silvicultural measures for systematic clearance (average of $0.98-2.52 \mathrm{~m}^{2} \mathrm{ha}^{-1} 2 \mathrm{th}^{-1}$ ), they have higher and wider value than initial tree-based clearance (average of incremental base 0.98-2.07 $\mathrm{m}^{2} \mathrm{ha}^{-1} 2 \mathrm{th}^{-1}$ ). The values for the periodical increment average of all species, Dipterocarpaceae, and non-Dipterocarpaceae are presented in Tables 1, 2, and 3.

Table 1 The basal area increment for periodic stands $\left(\mathrm{m}^{2} \mathrm{ha}^{-1} 2 \mathrm{th}^{-1}\right)$ for all species

\begin{tabular}{|c|c|c|c|c|c|c|c|c|c|c|}
\hline \multirow{2}{*}{\multicolumn{2}{|c|}{ Plots }} & $\mathrm{P} 1$ & P3 & $\mathrm{P5}$ & $\mathrm{P7}$ & P9 & P11 & $\mathrm{P} 13$ & $\mathrm{P} 15$ & $\mathrm{P} 23$ \\
\hline & & \multicolumn{9}{|c|}{$\left(\mathrm{m}^{2} \mathrm{ha}^{-1} 2 \mathrm{th}^{-1}\right)$} \\
\hline \multirow[t]{2}{*}{ PS } & Mean & 0.98 & 1.59 & 2.52 & 1.38 & 2.13 & 1.52 & 1.66 & 1.54 & 1.48 \\
\hline & SD & 0.12 & 0.38 & 0.60 & 0.23 & 0.43 & 0.35 & 0.51 & 0.48 & 0.35 \\
\hline \multirow[t]{3}{*}{ PPB } & Mean & 0.98 & 1.36 & 2.07 & 1.26 & 1.80 & 1.24 & 1.78 & 1.65 & 1.35 \\
\hline & SD & 0.12 & 0.37 & 0.41 & 0.21 & 0.27 & 0.16 & 1.46 & 0.85 & 0.45 \\
\hline & & HBT13 & HBT15 & HBT17 & HBT19 & HBT21 & HBT23 & HBT25 & HBT27 & HBT35 \\
\hline \multirow[t]{2}{*}{ CTR } & Mean & 0.95 & 0.93 & 1.53 & 0.85 & 1.23 & 0.83 & 0.81 & 0.78 & 0.76 \\
\hline & SD & 0.32 & 0.44 & 0.46 & 0.25 & 0.37 & 0.35 & 0.39 & 0.32 & 0.32 \\
\hline
\end{tabular}
Where: $\mathrm{P}=$ age of clearing (year); PS = systematic clearing; PPB = clearing based on foster trees; CTR $=$ without treatment; $\mathrm{SD}=$ Standard deviation; HBT $=$ age of logged-over forest (years). 
Table 2 The basal area increment for periodic stands $\left(\mathrm{m}^{2} \mathrm{ha}^{-1} 2 \mathrm{th}^{-1}\right)$ for the Dipterocarpaceae group

\begin{tabular}{|c|c|c|c|c|c|c|c|c|c|}
\hline \multirow[t]{2}{*}{ Plots } & $\mathrm{P} 1$ & P3 & P5 & P7 & P9 & P11 & P13 & P15 & P23 \\
\hline & \multicolumn{9}{|c|}{$\left(\mathrm{m}^{2} \mathrm{ha}^{-1} 2 \mathrm{th}^{-1}\right)$} \\
\hline $\begin{array}{ll}\text { PS } & \text { Mean }\end{array}$ & 0.35 & 0.71 & 1.15 & 0.58 & 0.96 & 0.80 & 0.92 & 0.89 & 0.85 \\
\hline SD & 0.08 & 0.24 & 0.34 & 0.14 & 0.29 & 0.30 & 0.38 & 0.21 & 0.29 \\
\hline PPB Mean & 0.34 & 0.57 & 0.90 & 0.51 & 0.70 & 0.52 & 0.56 & 0.48 & 0.49 \\
\hline SD & 0.15 & 0.22 & 0.36 & 0.21 & 0.30 & 0.19 & 0.16 & 0.16 & 0.17 \\
\hline & HBT13 & HBT15 & HBT17 & HBT19 & HBT21 & HBT23 & HBT25 & HBT27 & HBT35 \\
\hline \multirow{2}{*}{$\begin{array}{c}\text { CTR Mean } \\
\text { SD }\end{array}$} & 0.34 & 0.32 & 0.57 & 0.26 & 0.40 & 0.35 & 0.39 & 0.35 & 0.36 \\
\hline & 0.16 & 0.15 & 0.21 & 0.12 & 0.23 & 0.22 & 0.24 & 0.21 & 0.24 \\
\hline
\end{tabular}

Where: $\mathrm{P}=$ age of clearing (year); $\mathrm{PS}=$ systematic clearing; $\mathrm{PPB}=$ clearing based on foster trees; CTR $=$ without treatment; $\mathrm{SD}=$ Standard deviation; HBT $=$ age of logged-over forest (years)

Table 3 The basal area increment for periodic stands $\left(\mathrm{m}^{2} \mathrm{ha}^{-1} 2 \mathrm{th}^{-1}\right)$ for the Non Dipterocarpaceae group

\begin{tabular}{|c|c|c|c|c|c|c|c|c|c|}
\hline \multirow{2}{*}{ Plots } & $\mathrm{P} 1$ & $\mathrm{P} 3$ & $\mathrm{P5}$ & $\mathrm{P} 7$ & P9 & P11 & P13 & $\mathrm{P} 15$ & P23 \\
\hline & \multicolumn{9}{|c|}{$\left(\mathrm{m}^{2} \mathrm{ha}^{-1} 2 \mathrm{th}^{-1}\right)$} \\
\hline PS Mean & 0.63 & 0.88 & 1.36 & 0.80 & 1.17 & 0.72 & 0.73 & 0.74 & 0.74 \\
\hline SD & 0.09 & 0.19 & 0.35 & 0.12 & 0.18 & 0.12 & 0.21 & 0.21 & 0.21 \\
\hline \multirow{3}{*}{$\begin{array}{r}\text { PPB } \begin{array}{l}\mathrm{Me} \\
\mathrm{SD}\end{array} \\
\end{array}$} & 0.63 & 0.78 & 1.17 & 0.76 & 1.10 & 0.71 & 1.22 & 0.98 & 0.89 \\
\hline & 0.15 & 0.31 & 0.36 & 0.21 & 0.29 & 0.14 & 1.46 & 1.11 & 1.01 \\
\hline & HBT13 & HBT15 & HBT17 & HBT19 & HBT21 & HBT23 & HBT25 & HBT27 & HBT35 \\
\hline \multirow{2}{*}{$\begin{array}{c}\text { CTR Mean } \\
\text { SD }\end{array}$} & 0.61 & 0.62 & 0.96 & 0.60 & 0.83 & 0.48 & 0.42 & 0.45 & 0.45 \\
\hline & 0.22 & 0.32 & 0.33 & 0.17 & 0.28 & 0.18 & 0.35 & 0.32 & 0.31 \\
\hline
\end{tabular}

Where: $\mathrm{P}=$ age of clearing (year); $\mathrm{PS}=$ systematic clearing; $\mathrm{PPB}=$ clearing based on foster trees; CTR $=$ without treatment; $\mathrm{SD}=$ Standard deviation; $\mathrm{HBT}=$ age of logged-over forest (years)

Based on the main species composition, the group Dipterocarpaceae dominated by Shorea sp, Parashorea sp, Dipterocarpus sp, and non-Dipterocarpaceae dominated by a family of Lauraceae and Sapotaceae. This condition will produce different response values of periodic stand increment. The non-Dipterocarpaceae group has an average basal area increment (0.16$\left.1.48 \mathrm{~m}^{2} \mathrm{ha}^{-1} 2 \mathrm{th}^{-1}\right)$, which is a larger and wider range than the Dipterocarpaceae group (0.10$\left.1.15 \mathrm{~m}^{2} \mathrm{ha}^{-1} 2 \mathrm{th}^{-1}\right)$ in all forest conditions. After clearing the average increment in the $3 \mathrm{rd}$ year of the forest, it will increase almost two times compared to without treatment, especially for Dipterocarpaceae species groups. Differences in standing condition after logging will result in fluctuations of basal area incremental value for both Dipterocarpaceae and nonDipterocarpaceae types.

Differences in response to clearing techniques (systematic and tree-based) are clearly shown in the Dipterocarpaceae group. The systematic clearing technique provides a greater response to the periodic base increment than selective tree-based clearing or conditions without treatment. It 
shows a relationship between the growth space opening technique with periodic stand increment value for the Dipterocarpaceae group more visible than the non-Dipterocarpaceae group. The difference in each periodic increment response based on variations in site conditions has closely related to standing dimensions. It is mainly the case with canopy opening due to differences of canopy opening intensity of systematic and tree-based thinning techniques. Systematic thinning will produce evenly distributed growth space in the research plot so that the increment will be higher than the selective tree-based thinning approach. The response of the stand increment as a growth response is determined by the interaction of potential tree genetic (genetic) factors, environmental factors including climate (temperature, light, wind, rain) and soil and silvicultural techniques are given [7],[10],[18] and ecosystem [20].

\subsection{Correlation Period of Recovery for the increment of stand}

Analysis of variance showed that at a $99 \%$ confidence level, the treatment gave a significant difference to the increase in periodic basal area for Dipterocarpaceae. In contrast, it was not significantly different for the non-Dipterocarpaceae group. Further analysis to assess the clearing activities' effectiveness or thinning of the two release techniques can be combined. The regression analysis approach is carried out to see how much impact is given to the stand through the response of each basal increment area of the stand. The regression equation form was chosen based on the highest correlation and determination coefficient values and the lowest standard error for each type of group (Table 4).

Table 4 Relationship between the period after clearing with the stand basal area increment $\left(\mathrm{m}^{2} \mathrm{ha}^{-1} 2 \mathrm{th}^{-1}\right)$ for the Dipterocarpaceae (D), non Dipterocarpaceae (nD) and all types (SJ) groups

\begin{tabular}{cclccc}
\hline $\begin{array}{c}\text { Species } \\
\text { Grouping }\end{array}$ & $\begin{array}{c}\text { Condi- } \\
\text { tion }\end{array}$ & \multicolumn{1}{c}{ Regression Equation } & $\mathrm{R}^{2}$ & $\mathrm{SE}$ & $\mathrm{P}_{\text {value }}$ \\
\hline $\mathrm{D}$ & $\mathrm{HSP}$ & $\begin{array}{l}\mathrm{y}=0.002 \mathrm{x}^{3}-0.0483 \mathrm{x}^{2}+0.3495 \mathrm{x}+ \\
0.0387\end{array}$ & 0.2913 & 0.2512 & 0.03 \\
\cline { 2 - 6 } & $\mathrm{CTR}$ & $\begin{array}{l}\mathrm{y}=0.0007 \mathrm{x}^{3}-0.0148 \mathrm{x}^{2}+0.0927 \mathrm{x}+ \\
0.2408\end{array}$ & 0.0304 & 0.2157 & 0.13 \\
\hline $\mathrm{nD}$ & $\mathrm{HSP}$ & $\begin{array}{l}\mathrm{y}=0.0021 \mathrm{x}^{3}-0.0499 \mathrm{x}^{2}+0.351 \mathrm{x}+ \\
0.2967\end{array}$ & 0.2511 & 0.2599 & 0.05 \\
\cline { 2 - 6 } & $\mathrm{CTR}$ & $\begin{array}{l}\mathrm{y}=0.0003 \mathrm{x}^{3}-0.0134 \mathrm{x}^{2}+0.123 \mathrm{x}+ \\
0.4725\end{array}$ & 0.3181 & 0.2220 & 0.00 \\
\hline SJ & HSP & $\begin{array}{l}\mathrm{y}=0.004 \mathrm{x}^{3}-0.0982 \mathrm{x}^{2}+0.7006 \mathrm{x}+ \\
0.3355\end{array}$ & 0.3325 & 0.4400 & 0.01 \\
\cline { 2 - 6 } & $\mathrm{CTR}$ & $\begin{array}{l}\mathrm{y}=0.0009 \mathrm{x}^{3}-0.0282 \mathrm{x}^{2}+0.2157 \mathrm{x}+ \\
0.7133\end{array}$ & 0.1498 & 0.4029 & 0.04 \\
\hline
\end{tabular}

Where: $\mathrm{R} 2=$ Coefficient of determination; $\mathrm{SE}=$ Standard error; HBT $=$ Logged forest; HP $=$ Primer forest; $\mathrm{x}=$ time period after logging; $\mathrm{y}=$ periodic of base field increment value $\left(\mathrm{m}^{2} \mathrm{ha}^{-1}\right.$ $\left.2 \mathrm{th}^{-1}\right)$

The period after clearing has a relationship of approximately $30 \%$ to the basal area increment value of all Dipterocarpaceae $\left(\mathrm{R}^{2}=0.2913\right)$ and non-Dipterocarpaceae $\left(\mathrm{R}^{2}=0.2511\right)$ stand or all species group $\left(\mathrm{R}^{2}=0.3325\right)$. It showed that clearing/thinning affects each stand base field 
response, while the rest is influenced by other factors not defined in the analysis. It indicates that spacing thinning influences the stand acceleration productivity. Canopy opening due to logging or clearing activities will form a growth space that supports growth or increases the increment rate both individually and in stands. An optimal opening rate will support optimal growth [5],[18]. Meanwhile, the relationship between the period after land clearing and each species group's basal period area under various conditions is presented in Figure 3.

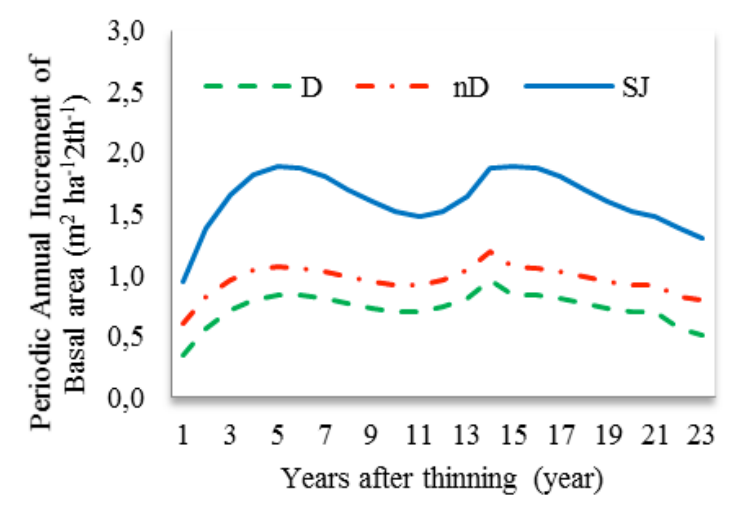

(a)

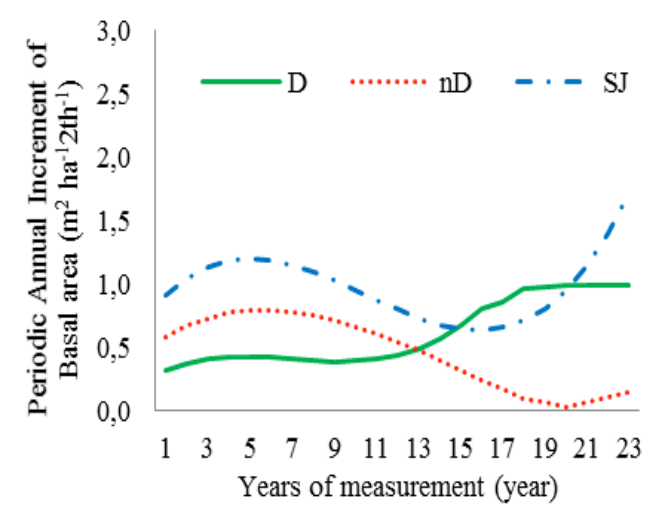

(b)

Figure 3 Relationship between the period after clearing with the periodic of increment base field $\left(\mathrm{m}^{2} \mathrm{ha}^{-1} 2 \mathrm{th}^{-1}\right)$ for Dipterocarpaceae (D), non-Dipterocarpaceae (nD) species and all species (SJ) under conditions (a) forest after clearing and (b) without treatment (control)

Increment measurement is often carried out in the stand assessment as many stand dimensions result from that can be harvested and removed at any given time. The increment of stands in forest relates to vegetation composition, site quality, tree health, age or period, and silvicultural actions. Approaches to grouping different stand types or dimensions can be used to observing variations in influence or species response to forest stands condition after logging [19]. Various reactions from classes or groups are reviews of the quantitative valuation characteristics of stand dimensions that are important for consideration of variations in species diversity of stand compilers [9], [10]. Reviewing stand composition characteristics is essential in studying tree species growth based on ecology and tree quality formation, especially for increasing the productivity of stands in production forests [4]-[5].

\section{Conclusion}

Variations in stand condition and clearance techniques will have different responses on the stand periodic basal area increment value. The Dipterocarpaceae group is more responsive to opening space compared to the non-Dipterocarpaceae group. It can be shown by increasing the basal area increment twice higher as the condition without clearing. Systematic clearing techniques will have more impact on the forest stand increment after logging acceleration. It indicates that a more appropriate approach to clearing/thinning stands is based on proportional stand basal area with the opening of growth space, which is quite evenly distributed in the stand. 
[1] F. H. Susanty, E. Suhendang, I. N. S. Jaya, and C. Kusmana, "Mortality and ingrowth pattern of dipterocarps in forest recovery in east Kalimantan," Biotropia (Bogor)., vol. 22, no. 1. 2015. DOI: 10.11598/btb.2015.22.1.297.

[2] F. H. Susanty, "Uji Formulasi Keragaan Karakteristik Biometrik pada Hutan Alam Bekas Penebangan di Kalimantan Timur," Pros. Semin. Nas. SILVIKULTUR KEVI "Penerapan Silvikultur untuk Pengelolaan Hutan dan Pengentas. Kem. tegakan, pp. 169-182. 2019.

[3] P. F. Newton, "Wood quality attribute models and their utility when integrated into density management decision-support systems for boreal conifers," For. Ecol. Manage., vol. 438, no. November 2018, pp. 267-284. 2019. DOI: 10.1016/j.foreco.2019.01.053.

[4] J. Baran, R. Pielech, P. Kauzal, W. Kukla, and J. Bodziarczyk, "Influence of forest management on stand structure in ravine forests," For. Ecol. Manage., vol. 463, no. February, p. 118018. 2020. DOI: 10.1016/j.foreco.2020.118018.

[5] H. Pretzsch, "Density and growth of forest stands revisited. Effect of the temporal scale of observation, site quality, and thinning," For. Ecol. Manage, vol. 460, no. January, p. 117879. 2020. DOI: 10.1016/j.foreco.2020.117879.

[6] J. R. Arévalo and J. R. Aboal, "Species turnover during secondary succession in a laurel forest stand 50 years after clearcutting," For. Syst., vol. 24, no. 1, pp. 1-5. 2015. DOI: $10.5424 / \mathrm{fs} / 2015241-05776$.

[7] H. Jactel et al., "Tree Diversity Drives Forest Stand Resistance to Natural Disturbances," Curr. For. Reports, vol. 3, no. 3, pp. 223-243. 2017. DOI: 10.1007/s40725-017-0064-1.

[8] J. R. Lozada et al., "Recovery after 25 years of the tree and palms species diversity on a selectively logged forest in a Venezuelan lowland ecosystem," For. Syst., vol. 25, no. 3. 2016. DOI: $10.5424 / \mathrm{fs} / 2016253-08178$.

[9] K. Teegalapalli and A. Datta, "Field to a forest: Patterns of forest recovery following shifting cultivation in the Eastern Himalaya," For. Ecol. Manage, vol. 364, pp. 173-182. 2016. DOI: 10.1016/j.foreco.2016.01.006.

[10] B. Sann, M. Kanzaki, M. Aung, and K. M. Htay, "Assessment of the Recovery of a Secondary Tropical Dry Forest After Human Disturbance in Central Myanmar," $J$. Trop. For. Sci., vol. 28, no. 4, pp. 479-489. 2016.

[11] A. Ali et al., "Response of understory vegetation, tree regeneration, and soil quality to manipulated stand density in a Pinus massoniana plantation," Glob. Ecol. Conserv., vol. 20, no. 1, p. e00775. 2019. DOI: 10.1016/j.gecco.2019.e00775.

[12] P. Sist et al., "The Tropical managed forests observatory: a research network addressing the future of tropical logged forests," Appl. Veg. Sci., vol. 18, no. 1. 2015. DOI: 10.1111 avsc. 12125 .

[13] J. Portier, S. Gauthier, G. Cyr, and Y. Bergeron, "Does time since fire drive live aboveground biomass and stand structure in low fire activity boreal forests? Impacts on their management," J. Environ. Manage., vol. 225, no. August, pp. 346-355. 2018. DOI: 10.1016/j.jenvman.2018.07.100.

[14] S. Sreelekshmi et al., "Diversity, stand structure, and zonation pattern of mangroves in southwest coast of India," J. Asia-Pacific Biodivers., vol. 11, no. 4, pp. 573-582. 2018. DOI: 10.1016/j.japb.2018.08.001.

[15] K. Bronisz and L. Mehtätalo, "Mixed-effects generalized height-diameter model for young silver birch stands on post-agricultural lands," For. Ecol. Manage., vol. 460, no. November 2019, p. 117901. 2020. DOI: 10.1016/j.foreco.2020.117901.

[16] Prodan, Forest Biometric, 1st Ed., Oxford, Pergamon Press, 1968.

[17] H. B, Forest Mensuration, 4th Ed., New Jersey (US), John Wiley \& Son Inc, 2003.

[18] F. H. Susanty, "Pola Kerapatan Dan Keragaman Tegakan Hutan Dipterokarpa Sekunder," J. Penelit. Hutan Tanam., vol. 17, No.1, no. Juni 2020, pp. 41-52. 2020. DOI: 10.20886/jpht.2020.17.1.41-51.

[19] F. H. Susanty, "Species Grouping of Shorea spp. Based on Responsive Scale of Periodic Individual Diameter Increment," IOP Conf. Ser. Earth Environ. Sci., vol. 394, no. 1. 2019. DOI: 10.1088/1755-1315/394/1/012054. 
[20] E. M. Andrade, M. J. S. Guerreiro, H. A. Q. Palácio, and D. A. Campos, "Ecohydrology in a Brazilian tropical dry forest: thinned vegetation impact on hydrological functions and ecosystem services," J. Hydrol. Reg. Stud., vol. 27, no. December 2019, p. 100649. 2020. DOI: 10.1016/j.ejrh.2019.100649. 